\title{
WTO/GPA Procurement Challenges faced by Chinese ICT manufacturers
}

\author{
Bogdan Lent \\ Faculty of Management \\ UTP University of Science and Technology \\ Bydgoszcz, Poland \\ bogdan.lent@utp.edu.pl
}

\begin{abstract}
Chinese ICT products due to the continuously improving ratio of price/performance are predestinated to win the WTO/GPA procurements worldwide. Paper presents the WTO/GPA procedures, taking under consideration the project management standard ISO 21500:2012 and law implementations in China, USA, Switzerland, Poland and Thailand. An assessment of potential challenges to Chinese bidders is given based on the example of the Swiss Government procurement. Basic recommendations are summarized in the conclusions.
\end{abstract}

Keywords: WTO, GPA, Public tender, award criteria, ICT transparency, ICT security

\section{INTRODUCTION}

Chinese ICT products gained worldwide renommé for their excellent price/performance ratio. This is particularly relevant in the procurements, which adhere to WTO/GPA rules. And by the policy the WTO/GPA ruling is advantageous to lower price/high performance (product features and quality) Chinese ICT products. Manufacturers like Avaya or Huwei dominated the public administration niche markets in data networks, optical, radio and cable access networks [1]. Yet, we cannot register a major breakthrough on the world market of WTO/GPA procurement. This paper analyses the procedures of WTO/GPA tendering process and the reasons for limited performance of Chinese participation in the international tenders from the point of view of the procuring organization, and may be viewed as a tutorial. The author manages large scale ICT projects with the WTO/GPA procurements procedures in Switzerland, participates and evaluates in the public procurements in Poland and Thailand, gained experience as a bidder in USA, 7 EU member countries, Singapore and China.

\section{WORLD TRADE ORGANIZATION}

WTO, World Trade Organization, is domiciled in Geneva, Switzerland and in force since 1.1.1996 [2]. WTO was established by the so called Uruguay Round 1995 upon having a vast number of countries signed the preliminary agreements on 15th of April 1994. The plurilateral agreements facilitate primarily the international trade: providing systems for delivery and payment among the business in various countries.

Governmental spending contributes $10-15 \%$ of GNP worldwide [ibidem]. Several governments in strive for better price/performance and competitiveness among the bidders initiated the negotiations on common and internationally open procurement rules. The relevant Agreement on Government Procurement (GPA) was already negotiated during the Tokyo Round and entered into force on January 1981 [3]. The agreement in its present version negotiated in the Uruguay Round, has only 28 members (not all WTO countries), therefore it is an attachment to the WTO Agreement.

The basic objective of the GPA Agreement is to guarantee fair and non-discriminatory conditions of international competition through transparency of all public spending.

The threshold value for procurements which subject to the Agreement is currently 130'000 so called SDR (Special Drawing Rights) SDR were created by the IMF (International Monetary Fund) and allocated to the member countries proportionally to their IMF quotas. The quota for construction works is 5 million SDR. One SDR is currently (2017) Chinese Yuan 9.316, Euro 1.274 or US \$ 1.35 [4].

The organizations issuing the tenders in the member countries are obliged to award the tender to the lowest bidding or most advantageous bidder, who is capable to realize the tender according to the evaluation done by the tender issuing organization. Meantime in many economies, also the procurements of the majority of public entities beyond the governmental authorities comply with the WTO/GPA rules. Even if these procedures are not mandatory for procurements below the threshold values, in most cases also there one of the WTO/GPA tender procedures is applied. This sets the limits both for tenders as well as for bidders.

\section{WTO/GPA PROCUREMENT}

\section{A. Tendering procedures}

- The GPA foresees three tendering procedures: Open tendering procedures, unrestricted, where any supplier may submit a tender,

- Selective tendering procedures where selected suppliers are invited to submit the tender.

- Limited tendering procedures (extensions to the contracts awarded according to above procedures, exclusive rights, urgency, innovation, absence of tenders, commodity market, exceptionally advantageous conditions results of design contests). 
In 2006, after accepting several provisions to GPA, in particular in Doha Development Agenda [5]:

- The electronic bidding process has been adopted. Quotations in reverse auction lower the prices on-line, the lowest bidder is awarded the contract. GPA (Article XIV) admits in selective tendering as well as in other forms in case, when no obviously most advantageous tender may be selected, to conduct.

- The negotiations. However, they shall be focused on identifying the strengths and weaknesses of the tenders, not on the prices.

Most countries adjusted their national laws to accommodate the above procedures and simultaneously regulating the procurement in the areas below the threshold values of WTO $[6,7,8,9,10]$.

\section{B. Content of invitation to participate or call for tenders}

An invitation to participate in the tender, or directly call for tenders, shall provide four blocks of information as shown in Table 1 and Table 2 (reduced information for the qualification for of the bidders in the invitations).

TABLE I. PROCEDURAL AND GENERAL INFORMATION ABOUT THE SCOPE (EXPECTED OUTPUT) IN CALL FOR TENDERS/INVITATIONS

\begin{tabular}{|c|c|c|c|}
\hline Block & Subject & Id. & Contents \\
\hline \multirow[t]{10}{*}{$\mathrm{P}$} & \multirow{10}{*}{$\begin{array}{l}\text { Procedural } \\
\text { information }\end{array}$} & $\mathrm{P} 1$ & Issuer of the call/invitation \\
\hline & & $\mathrm{P} 2$ & Purchasing organization \\
\hline & & P3 & Tendering procedure \\
\hline & & $\mathrm{P} 4$ & Deadline for submissions \\
\hline & & P5 & Place for submissions \\
\hline & & P6 & Other conditions like multiple offers \\
\hline & & P7 & Admission of consortia \\
\hline & & P8 & (Option) Bid bond \\
\hline & & P9 & (Option) Protest/Challenge procedure \\
\hline & & $\mathrm{P} 10$ & Other conditions like multiple offers \\
\hline \multirow[t]{4}{*}{ G } & \multirow{4}{*}{$\begin{array}{l}\text { General } \\
\text { information } \\
\text { about the scope } \\
\text { (expected output) }\end{array}$} & G1 & Subject (expected outputs) \& timing \\
\hline & & $\mathrm{G} 2$ & Evaluation criteria \\
\hline & & G3 & Contract proposal \\
\hline & & G4 & (Option) Follow-up orders \\
\hline
\end{tabular}

Source: Own based on data in references 3 and 7 to 10

TABLE II. INFORMATION CONTENTS OF INVITATION OR CALL FOR TENDERS-ELIGIBILITY AND TECHNICAL SPECIFICATIONS

\begin{tabular}{|c|l|l|l|}
\hline Block & Subject & Id. & Contents \\
\hline \multirow{2}{*}{$\mathrm{E}$} & \multirow{2}{*}{$\begin{array}{c}\text { Eligibility } \\
\text { criteria }\end{array}$} & E1 & Legacy of business activity \\
\cline { 3 - 4 } & & E2 & (Option) Regulated taxes \\
\cline { 3 - 4 } & & E3 & (Option) Regulated social insurances \\
\cline { 3 - 4 } & & E4 & (Option) No relevant law perjury \\
\cline { 3 - 4 } & & E5 & (Option) Technical capability \\
\cline { 3 - 4 } & & E6 & (Option) Financial capability \\
\hline $\mathrm{T}$ & $\begin{array}{l}\text { Technical } \\
\text { Specifications }\end{array}$ & T2 & Tuantity/Quality criteria \\
\hline
\end{tabular}

Source: Own based on data in references 3 and 7 to 10
In all mentioned above national laws (USA, Switzerland, Poland, and Thailand) and in practice these recommendations are fully implemented (China as far as it could be verified).

The specifications of Outputs, even if they describe the human labor services, are called in several regulations "Technical Specifications" [11] or "Terms of Reference" (e.g Thailand)

The specifications of Outputs, even if they describe the human labor services, are called in several regulations "Technical Specifications" [11] or "Terms of Reference" (e.g Thailand).

However, in international disputes the term "Terms of Reference" is a compulsory document containing the identification data, claims and issues of the contract parties [12]. As this is broader meaning than the Technical Specifications, it is suggested to use the term "Technical Specifications" only (as e.g. in Switzerland).

The definition of the Technical Specifications in e.g. European Public Procurement law, in various Appendices, says that these are prescriptions of the intended procurement, which permits the procured work, a material, a product, or a supply to fulfill the use for the purchasing organization [13]. To keep all options open, unless purchaser or project regulations restrict them, the Technical Specifications apply whenever possible standards and rather shall describe the desired performance of the planned procurement, not the possible solutions. Performance is given by:

- the needed functionality (e.g. network shall be fully operational at minimum 2'000 users simultaneously)

- non-functional demands (e.g. only earth cabling admitted) and

- $\quad$ given quality of the delivery (Quality of Service 98\%)

Time schedule of supplies subjects to several modifications during the project life cycle. Nevertheless, the project needs elaborated in the PSP project schedule plan are the starting point here. The demanded deliveries shall be foreseen as late as possible, yet with a sufficient buffer for the eventual delays.

\section{Award Algorithm}

The evaluation of tender in any of the above described procedures follows two steps.

\section{1) Evaluation of the eligibility of tender}

Here the criteria, advisably set in accordance with the WTO rules, can lead to only binary decision: comply or not comply. In public procurements typically these are on-time submission, the formal authorization to the business activity in a given area, regulated relation to the tax office, social insurances, sometimes clear criminal record in respective area (Table 2, Block E). It may also demand the proof of financial or technical capability to deliver. In a selective procedure this can be done in the primary qualification of the bidders; in other procedures - upon reception of the offer. 
2) Evaluation of the value of tender

WTO article XIII, P.4 b) admits the awarding of the contract either based on one of the two options:

- "Lowest Tender" meaning that the basis for awarding contracts is the lowest price among the tenders. It is applicable to the commodities and very good specified pro-curements, or

- "Most Advantageous", in the USA known as "Best Value" offer, which optimizes quality, cost and efficiency, among responsive and responsible bidders.

For various reasons the "Lowest Tender" was ever since Poland changed from commanding economy towards democratic one, for twenty years the only applied awarding scheme. This resulted in various pathologies both on the procuring as well as on the bidding sides. Until during the preparation for prestigious UEFA EURO 2012 soccer championship expressway constructors cheated in such a way, that whatever they have done, had to be rebuild instantly and afterwards they bankrupt en mas.

"Most Advantageous" evaluation combines the costs with the performance as described above in Section 2.2. Depending on the strategy and type of procured goods the weighting (ratio) of costs vs. performance in the evaluation varies between 80:20 (commodity routine procurement) up to $30: 70$ (innovation).

Cost evaluation follows in most cases one of the two schemes: unlimited price range (1) or price range limited to the accepted offered most expensive quotation not exceeding double the lowest price of any tender (2):

$$
\begin{aligned}
& P E(\text { given tender })=(H-G T) /(H-L) \\
& P E(\text { given tender })=(2 L-G T) / L
\end{aligned}
$$

Where:

PE: Price evaluation of a given tender,

$\mathrm{H}$ : $\quad$ Highest price of any tender

GT: Price of given tender

L: $\quad$ Lowest price of any tender

More sophisticated non-linear schemes are used when no exclusion is desired, yet they lead in practice to similar results like scheme (2) above, saving the procure the effort to evaluate the tender.

\section{Time Planning}

Two relevant processes in ISO 201500:2012 [14] regulate the procurement management:

- 4.3.35 Plan Procurement

- 4.3.36 Select Suppliers

The third process: 4.3.37 Administer Contracts relates to the contract management, which cover the stage still in the project phases but also the time after project is closed and the outputs (products) are used in daily operation (whole life cycle). It is beyond the scope of this paper, yet it is worth of dedicated considerations.

\section{1) Process 4.3.35 Plan procurement}

Plan Procurement is a primarily task of the purchasing organization. Depending on the quality of the elaborated technical specifications the preparation may take up to several years. In this phase also the basic decision: "Make" or "Buy"? is taken, and the tender management team is organized. Table 3 illustrate the best and worst case time durations experienced by the author.

TABLE III. Time Estimation for the Procurement Planning Process

\begin{tabular}{|r|l|r|r|}
\hline No & Activity & $\begin{array}{l}\text { Best case } \\
\text { time [days] }\end{array}$ & $\begin{array}{l}\text { Worst case } \\
\text { time [days] }\end{array}$ \\
\hline 1 & Develop Procurement Objectives & 40 & 1 '000 \\
\hline 2 & Obtain purchaser/superior acceptance & 1 & 60 \\
\hline 3 & Decide Make or Buy & 7 & 60 \\
\hline 4 & Select tender procedure & 7 & 40 \\
\hline 5 & Select tender management team & 2 & 40 \\
\hline 6 & Elaborate tender time schedule & 10 & 30 \\
\hline 7 & Obtain purchaser/superior acceptance & 1 & 60 \\
\hline & Total Procurement Planning Process & 68 & $1 ' 290$ \\
\hline
\end{tabular}

Source: Own based on experience in countries mentioned in this paper

1)

Process 4.3.36 Select Suppliers

Here the strong WTO/GPA regulations induce firstly the minimal/maximal duration of individual steps in the procedures and secondly impose on the participating countries the necessity of establishing the protest/claim organizations, where any of items: The procurement procedure, The content of the call, and The decision may be challenged. Therefore, the shortest feasible and the longest likely to be time estimations (special cases excluded) are given in Table 4.

The procurement preparation and planning process is not a fast track exercise: somewhere between 6 months and 6 years shall be taken into consideration during the project planning. And yet, the delivery time starts first with the contract signing ...

TABLE IV. Time Estimation For the Select SuPPLiERS Process

\begin{tabular}{|r|l|r|r|}
\hline No & Activity & $\begin{array}{l}\text { Best case } \\
\text { time [days] }\end{array}$ & $\begin{array}{l}\text { Worst case } \\
\text { time [days] }\end{array}$ \\
\hline 8 & Prepare and issue the call for tenders & 5 & 30 \\
\hline 9 & Select the potential suppliers (optional) & $25+10$ & $25+60$ \\
\hline 10 & Do changes due to challenges (optional) & $7+20$ & $7+20$ \\
\hline 11 & Wait due time for bidders to submit offers & 7 & 40 \\
\hline 12 & Evaluate the offers & 7 & 180 \\
\hline 13 & Obtain purchaser/superior acceptance & 1 & 60 \\
\hline 14 & Time for challenges of award & 7 & 30 \\
\hline 15 & Final contract negotiations and signing & 1 & 30 \\
\hline & Total Procurement Planning Process & 85 & 482 \\
\hline
\end{tabular}

Considerable resources are involved in this process: somewhere between 60 and 1000 Workdays of the tender preparing organization shall be calculated and added atop of the procurement costs.

\section{EXAMPLE OF THE WTO/GPA PROCUREMENT IN SWITZERLAND}

It shall be noticed that worldwide among all members of WTO and all members of GPA only Switzerland and Singapore adopted both agreements into national laws without any modifications. 
2011 Swiss Border Guard and Customs decided to optimize their processes and replace the National Command and Control System in four operational centers and the fifth central test and training center. The ICT-System is integrated within the governmental and police systems environments, with interfaces to the international customs, Interpol and Schengen. Additionally the complexity is increased by simultaneous multilingual operation and close integration with a police command and control center in one of the country regions.

A team of $6100 \%$ FTE and another two teams of 8-12 persons, each $10-20 \%$ FTE worked on the issues in the two processes described above:

- 4.3.35 Plan Procurement: 01.01.2011 - 30.10.2011

- 4.3.36 Select Suppliers: 01.11.2011 - 31.03.2013

The Open tender procedure (a) and the "Most Advantageous" evaluation scheme had been chosen. Price included the total costs of ownership covering:

- Development or Adaptation of the ICT System

- Integration and assistance until the error-free operation in all $4+1$ centers

- 10 years support costs (excluding ex-ante variable costs of the use of the Swiss Government ICT infrastructure)

The weight of the price was $37 \%$. Received were 7 tenders between CHF 13 and 37 Million. No quotation from China has been received. Applied scheme (2) (see section 2.3.2) led to the rejection of the two most expensive quotations. One offer had formal error: submitting the quotation past the deadline. Four quotation were further evaluated by a team of 11 persons.

The Eligibility Criteria E1-E6 (see section 2.2., Table 1) were detailed in the 17 precisely described requirements (e.g. one description of 130 words) equally weighted and with a binary evaluation scale ( $1=$ met, $0=$ not met). All Eligibility Criteria had to be met for further evaluation. Challenges to Chinese offer might have been in particular:

- SPOC: local Single Point of Contact and local service organization with fluent one of the official national languages

- Personal Security Admission by the procurer authorities of key personal involved in a project

- Involved staff of the bidder with local working permits

Several specification groups with various evaluation schemes implemented the T1 block (see section 2.2, Table 2). The first three groups, also with binary evaluation criteria, were misleadingly called also "Technical Specification": Functional (16 criteria), Technical Customs (16 criteria), Technical Police (17 criteria). Each criterion contained 1-20 specific requirements. Basically any one criterion not met put the tender in question. Majority of these requirements author assesses as feasible to be met by the Chinese tenderers. A challenge to Chinese offer might have been:

- Multilingual simultaneous real time operation of the system: In case of an emergency the command and control operation from Geneva (French language) had to be instantly and correctly handed over to Basel control center (German language) with all oral and written communication available in this (new) second language. Beside the simultaneous operation and translation between those two the Italian language documentations and commands had to be implemented.

- Functional availability to language maintenance module by the local system administrator.

- Interconnectivity with all relevant military and security systems. Here the challenge for Chinese quotation was certainly not the functional capability but the proof, that no unlawful activity as viewed by the procurer, is conducted by the equipment in operation.

- Information Security and Data Security (ISDS) compliance with procurer rules. Chinese tenderer might have to go further than the western counterparts beyond the declaration to prove that Chinese products comply.

- Tough MTTR and reactions time, forcing the bidder to establish a sound service organization locally with the procurer.

Next two groups are called "Selection criteria": one functional (18 criteria with a binary or tertiary scale, equally weighted among themselves), weighted with $14 \%$ in total evaluation and one technical (32 criteria with a binary or tertiary scale, equally weighted among themselves), weighted in total with $31 \%$. The differentiating and challenging for Chinese bidders might have been only:

- Evaluation of the speed and quality of the simultaneous translation of written documentation (also transcripts of oral dialogs) between four languages: German, French, Italian and English (for international police cooperation purposes).

The remaining $18 \%$ weight was given to the presentation and 2-days evaluation by 50 stakeholders from all areas of users, operators and maintenance, as demanded in the call for tenders. Here again 12 criteria were equally weighted. Each bidder had to implement a given process and demonstrate it using the offered solution.

All results from individual evaluators has been collected, equivocally summarized and mean result for each of the four finalists has been calculated.

Steps 12-15 (Table 4 in section 2.4.2.) took 9 months. The supplier who quoted about CHF 16 Million had been chosen. The implementation in several steps begun in 2013 and is planned to close in 2018 .

\section{CONCLUSIONS}

The WTO/GPA process is a tedious and expensive endeavor. With 128 complex criteria (each containing numerous items), around 2 years of preparation and procurement time, further 5 years delivery, about 10 FTEs over two years and approximately CHF 50'000.- effort of each bidder it calls for serious approach both, from the purchasing organization as well as from the bidder. The purchasing organization has to assure sufficient budget and its availability 
over several years (most public founded organizations have yearly budget and thus can commit only year-based expenses). The approach "to learn" through the calls is considered irresponsible: all bidders invest substantial means and expect at least one of them to win (author made this experience several times). Also opposite: an evaluation is an expensive process, so the quotations with unprepared or intentionally lousy quality as "sensing balloons" shall be avoided as irresponsible, too.

Obviously the lower value procurements are done with scaled down efforts - yet the procedures remain the same.

Although the stakeholder management remains a key marketing and sales issue, the attention and effort are moving towards anonymous, objective product evaluation, with benefits to the economy and the society.

The international standardization and tendering possibility contribute to higher competitiveness and thus high efficiency of public investments across the globe. We register even SME companies courageously bidding on continents thousand $\mathrm{km}$ away.

Specifically the Chinese bidders face the problem of mistrust. So they have to go an extra miles to prove they are "whiter than white" to win the confidence and trust of the procurers by:

- The establishment of strong locally available staff fulfilling the language and formal criteria. This may follow either by the subsidiaries or (recommended) through buy-in into established enterprises with recognized brand names. The last is already successfully under course.

- Engineer locally highly customized products.

- Voluntary submission and proof of conformity with recognized standards like e.g. ISO 27000 series [15] and provisions for the referential transparency and opacity [16].

- And still the best is just to develop a crystal clear and transparent products. It becomes more difficult to hide any spyware [17].

In admiration of the Chinese economic and social successes author wish the world to have a sound base to develop an unconditional trust in Chinese ICT products.

\section{ACKNOWLEDGMENT}

Author is grateful to the authorities in Switzerland, Poland, Thailand for the opportunity to be deeply involved in elaboration of the procurements and to gain this valuable experience.

Author expresses his gratitude to the reviewers for their valuable comments.

\section{REFERENCES}

[1] M. Fabbi, A. Lerner, Magic Quadrant for Data Center Networking, Gartner Repports 11 May 2015, ID G00264124, New York, 2015

[2] WTO Official documents of the Committee on Government Procurement, p.1 cont. http://www.wto.org/english/res_e/ publications_e/wto_agree_series_e.htm accessed 11.02.2017

[3] Urugway Round Agreement, Agreement on Government Procurement, p.1 cont. http://www.wto.org/english/ docs.e/legal_e/gpr-94_01_e.htm accessed 11.02.2017

[4] International Monetary Fund, Currency units per SDR for February 10, 2017, p.1 cont. https://www.imf.org/external/np/fin/data/ rms_mth.aspx?reportType=CVSDR accessed 11.02.2017

[5] S. Wunsch-Vincent, J. McIntosh, (editors), WRO, E-commerce, and Information Technologies, From the Uruguay Round through the Doha Development Agenda, A Report for the UN ICT Task Force, Markle Foundation, p. 22, 2004

[6] Chinese Government Report Trade Policy Review WT/TPR/G/342, p. 4 cont. https://www.wto.org/english/tratop_e/tpr_e/g342_e.pdf accessed 11.02.2017

[7] GSA, DoD, NASA FAR, Federal Acquisition Regulation, Vol. 1 and 2, General Services Administration, Washington, USA, p.1 cont., 2005.

[8] Sejm Polski KC, Kodeks cywilny, ustawy prawa handlowego i gospodarczego, p.1 cont. http://isap.sejm.gov.pl/Keyword Servlet? viewName=thasK\&passName-=kodekscywilny accessed 11.02.2017

[9] Schweizerische Eidgenossenschaft, BöB, Bundesgesetz über das öffentliche Beschaffungswesen BöB (SR 172.056.1; SR 172.056.11); p.1 cont. http://www.admin.ch/ch/d/sr/172_056_1/index.html accessed 11.02.2017

[10] PMO, PMO's Regulation on Procurement B.E. 2535, PMO Bangkok, Thailand, p.1 cont., 1992

[11] P. Neumann, United Nations Procurement Regime, in P. Hilpold, A. Reinisch, (Eds), Völkerrecht Europarecht und Internationales Wirtschaftsrecht, Peter Lang GmbH, Frankfurt, Germany, p.90, 2008

[12] E. Schäfer, H. Verbist, Chr. Imhoos ICC Arbitration in Practice, Kluwer Law International, The Hague, The Netherlands, p. 89, 2005

[13] J.M. Hebly European Public Procurement: legislative history of the 'utilities' directive: 2004/17/ES, Kluwer Law International, AH Alphen an den Rijn, The Netherlands, p. 83, 2008

[14] ISO 21500:2012 Guidance on Project Management, ICS 03.100.40, ISO Geneva, Switzerland, p. 36-37, 2012

[15] ISO/IEC 27034:2011 - Information technology - Security techniques Application security- Protocolls http://www.iso27001security.com/html/ 27034.html accessed 11.02.2017

[16] M. Keil, S.N. Guria, A.Schlegel, M.Geffken, P.Thiemann, Transparent Object Proxies for JavaScript in J.T. Boyland (Eds) 29th European Conference on Object-Oriented Programming (ECOOP'15), p. 149-173, http://drops.dagstuhl.de/opus/volltexte/2015/5229/pdf/19.pdf accessed 11.02 .2017

[17] A.Risteski, M. Bogdanoski, M. Stoilkovski, M. Jovanovic, Cyber Security Issues of Telecommunication Infrastructure, in A. Vaseashta, P. Susmann, E. Braman, (Eds) Proceedings of the NATO Advanceed Research Workshop on Best Practices and Innovative Approaches to Develop Cyber Security and Resiliency Policy Framework, IOS Press BV, Amsterdam, p. 18 cont. 2014 